\title{
Guest Editorial: Special Issue on Global Hydrological Datasets for Local Water Management Applications
}

\author{
Geert Sterk $^{1} \cdot$ Frederiek Sperna-Weiland $^{2} \cdot$ Marc Bierkens $^{1}$ \\ Published online: 11 May 2020 \\ (C) Springer Nature B.V. 2020
}

\section{Introduction}

The global water resources and flows are under pressure due to climate impacts and human interventions such as hydro-power dam operations and water abstractions for agriculture, industry, tourism and domestic use (Haddeland et al. 2014). In many areas the per-capita water availability is decreasing due to climate and demographic changes (Faures 2006). Projected climate change will aggravate hydrological extremes, notably floods and droughts (Patz et al. 2005), which in combination with continued population growth may enhance water scarcity (Hagemann et al. 2013). Management of water resources will become an increasing challenge in the twenty-first century, especially in those areas where large variations in the water availability occur.

To assist operational water management activities, especially in those areas where in-situ measurements are lacking, new tools and hydrological datasets are required to test alternative management options to adapt to future hydrological conditions. To do so, it is important to have access to historical hydrological data, which can provide information about past hydrological extremes. These data can be used to test alternative water management decisions and provide probabilities of water resources availability under a variety of climatic conditions. In many developed countries with a good hydrological measurement network and long time series of data such water management evaluations can be easily made. On the other hand, there are many countries in the world where such time series of hydrological data are missing for most of their major watersheds.

When good-quality data are missing, use can be made of re-analysis datasets of water resources. However, until recently only a few of such global re-analysis datasets were available (Schellekens et al. 2017). Examples are the Global Land Data Assimilation System (GLDAS) from NASA (Rodell et al. 2004) and ERA-Interim/Land, the ECMWF Re-Analysis product (Balsamo et al. 2015). The recently terminated project 'Global Earth Observation for

Geert Sterk

g.sterk@uu.nl

1 Department of Physical Geography, Utrecht University, P.O. Box 80.115, NL-3508 TC

Utrecht, The Netherlands

2 Deltares, Rotterdamseweg 185, NL-2629 HD Delft, The Netherlands 
Integrated Water Resources Assessment' (eartH2Observe), which was funded through the EU Framework 7 programme, has produced two new global water resources re-analysis (WRR) datasets, which cover the years 1979-2012.

\section{2 eartH2Observe Products}

Compared to the previous re-analysis datasets, which were based on a single land surface model, the eartH2Observe WRR datasets are based on a multi-model ensemble consisting of ten global models (Table 1). The two WRR products from the eartH2Observe project are at different spatial resolutions. The Tier 1 WRR used the WATCH Forcing Data methodology applied to ERA-Interim reanalysis (WFDEI; Weedon et al. 2014) to run the ten models and provides the hydrological variables at $0.50^{\circ}$ spatial resolution and 3-hourly time step. For the Tier 2 WRR an improved rainfall forcing dataset at $0.25^{\circ}$ spatial resolution and 3-hourly timestep was used. This product, the Multi-Source Weighted-Ensemble Precipitation (MSWEP; Beck et al. 2017), is based on a combination of satellite data, rain gauge data and atmospheric re-analysis models to produce the best possible global rainfall product. The MSWEP product in combination with the other atmospheric variables from the downscaled (from $0.50^{\circ}$ to $0.25^{\circ}$ ) WATCH product was used to force all ten models in the Tier 2 WRR.

All data from the eartH2Observe project have been made freely available through the eartH2Observe Water Cycle Integrator (WCI) data portal (https://wci.earth2observe.eu/). This includes a great number of model output variables (soil moisture, evapotranspiration, river flows, drought indices, etc.) but also the forcing data used to run the models, as well as Earth Observation (EO) datasets. The data portal allows to display global and regional maps of different hydrological variables (Fig. 1), and to produce time series graphs of selected variables. In addition, all global data files as produced by the eartH2Observe project can be freely downloaded for further analyses.

One of the aims of the eartH2Observe project was to test the WRR Tier 1 and Tier 2 datasets at local level. For this purpose, country-based case studies were conducted to evaluate the data quality and applicability of the different global hydrological WRR and remote sensing products. The focus of most of the case studies was on improved hydrological modelling of a specific river basin using the developed datasets. In addition, all case studies evaluated the potential use of the eartH2Observe global hydrological data for development of tools for water

Table 1 Global models used in the eartH2Observe water resources re-analysis quantification

\begin{tabular}{lll}
\hline Model & Type of model & Reference \\
\hline HTESSEL-CaMa & Land surface model & Balsamo et al. (2009) \\
JULES & Land surface Model & Best et al. (2011) \\
LISFLOOD & Hydrology model & Van der Knijff et al. (2010) \\
ORCHIDEE & Land surface model & Krinner et al. (2005) \\
PCR-GLOBWB & Hydrology model & Sutanudjaja et al. (2018) \\
SURFEX-TRIP & Land surface model & Decharme et al. (2010) \\
SWBM & Hydrology model & Orth and Seneviratne (2013) \\
W3RA & Hydrology model & Van Dijk et al. (2013) \\
WaterGAP3 & Hydrology model & Flörke et al. (2013) \\
HBV-SIMREG & Hydrology model & Lindström et al. (1997) \\
\hline
\end{tabular}




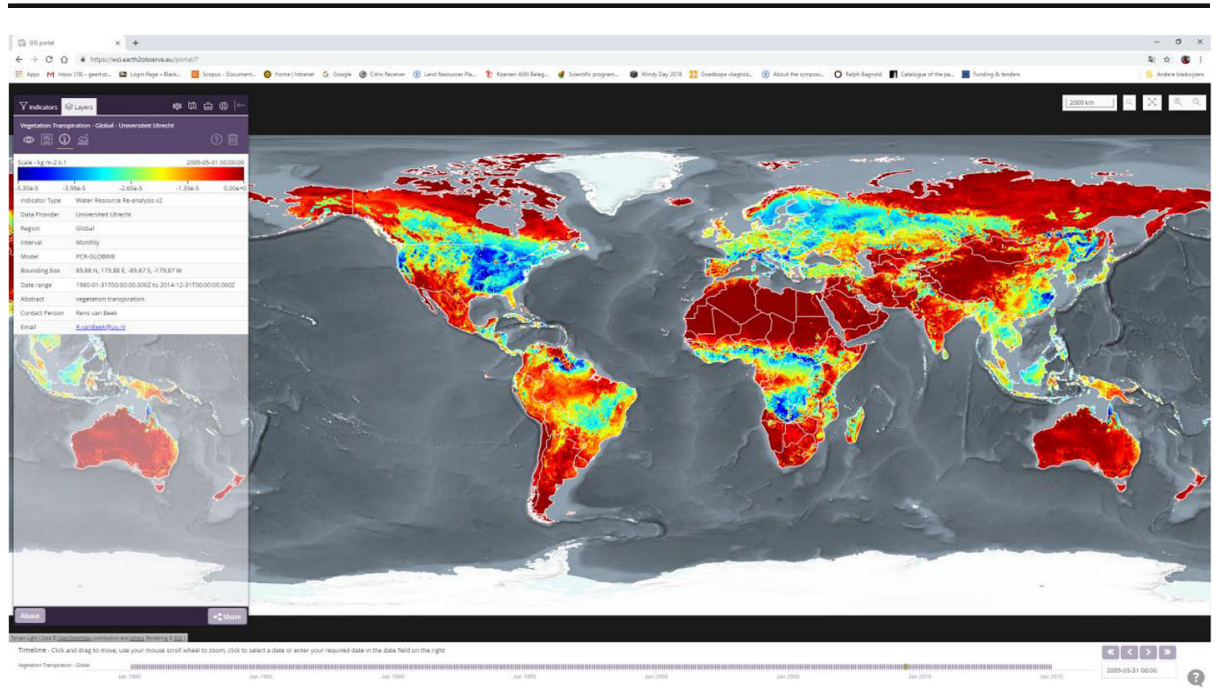

Fig. 1 Screenshot of the eartH2Observe data portal. Graph shows the vegetation transpiration for May 2009, based on PCR-GLOBWB simulation using the MSWEP forcing data (WRR Tier 2)

management at national or river basin levels. A total of six case studies were carried out in seven countries, which are different in available water resources, and face different problems in basin-scale and national-scale water management. In every country the eartH2Observe project collaborated with end-users to test the WRR products and develop jointly improved tools for water management purposes. Every case study started with a workshop during which the needs and objectives of the participating end-users were determined, and the detailed work plan for the case study was developed. The main results and water management applications resulting from the case studies are published in this special issue to assist applications of developed methods in other areas.

\section{3 eartH2Observe Case Studies}

The Mediterranean case study was conducted in Morocco and Spain. The focus of the work in Morocco (Strohmeier et al. 2019) was on drought and water management in the Oum Er Rbia basin. Two hydrological models (SWAT and PCR-GLOBWB) have been set-up for the basin, and runs were performed using in-situ and the eartH2Observe forcing data. In addition the Tier 2 WRR multi-model ensemble was used to analyse drought in the Oum Er Rbia basin and entire Morocco. In Spain the focus of the research was the assessment of groundwater and drought. Two land surface models, LEAF-HYDRO and ISBA have been applied at high spatial resolutions $(2.5$ and $5.0 \mathrm{~km}$ ), and were forced by the WFDEI and MSWEP forcing data and a local product (SAFRAN). Groundwater recharge and groundwater levels were simulated for entire Spain (Quintana-Segu et al. 2019).

The Ethiopia case study focussed on the upper Blue Nile basin, which is one of the most important water sources in Africa. Water resources assessments in the area are hampered by a lack of reliable precipitation data. Global precipitation products were compared with in-situ data, and tested for hydrological modelling of the upper Blue Nile. The analysis was extended towards modelling using the CREST hydrological model, and this local model was compared 
with the Tier 1 and 2 WRR global model results. The modelled discharges were compared with measured discharges at three stations, and it was evaluated which global hydrological products are useful for water management in the Blue Nile basin (Lakew et al. 2019).

In Colombia, the case study was dealing with the water resources in the Magdalena river basin. Several models (DWB, VIC, wflow-hbv, WaterWorld) were set-up and tested with different forcing datasets. A first step in the research was the comparison of EO precipitation products with in-situ measurements. Rainfall data from the WRR2 forcing dataset performed best, and was much improved compared with the earlier coarse resolution WRR1 forcing data. Also, a comparison between WRR2 global model discharge results and the measured values at many sub-basins was made. Some of the uncalibrated global models provided good estimates of discharge. The hydrological modelling was used to assess water availability in the Magdalena basin using different indicators. Such information is useful for basin-level planning and water management (Rodríguez et al. 2019).

The focus of the Bangladesh case study was on the quantification of water resources variability in the Brahmaputra river basin. Several EO-based rainfall products were compared with in-situ measured rainfall. On a monthly scale, the EO-based products performed well, but were much less accurate on a daily scale. The WRR Tier 2 forcing rainfall data showed the best correlation with the measured rainfall data. The MIKE-BASIN model was used to simulate river flows using in-situ and EO-based rainfall. All satellite based products resulted in an underestimation of discharge, with TRMM rainfall giving the best results. The WRR1 and WRR2 global hydrological simulations were also compared with measured discharges. The global models generally underestimate the peak discharges, but the ensemble mean gave reasonable results and can be used for flood analysis in the Brahmaputra basin. As a final step, a bias correction to the ensemble mean was made which provides an even better representation of measured discharge, even better than the locally modelled discharge with MIKE-BASIN (López López et al. 2020).

The Australia case study focussed on drought and irrigation planning. EO-based soil moisture products were tested and used for hydrological model assimilation in the Murrumbidgee river basin. The original AMSR-E soil moisture and a new, sharpened AMSR-E soil moisture product were compared with measured and modelled soil moisture over entire Australia. Both products showed a good agreement with the measured and modelled soil moisture. The sharpened AMSR-E soil moisture product was used for data assimilation in the PCR-GLOBWB hydrological model for the Murrumbidgee basin. Using soil moisture in the assimilation resulted in more improvement in discharge modelling than using measured streamflow. Combining the two types of data in model assimilation gave the best improvement (López López et al. 2016). In addition, the global models from the WRR2 were used to evaluate the amount of water available for irrigation. In the study the influence of hydrological variability on water availability was determined, and the benefit of using an ensemble of global hydrological model outputs for designing the size of an irrigation area was evaluated. The annual agricultural production as influenced by the actual occurrence of water scarcity was generated for a reference and alternative irrigation area sizes. The main results obtained show that an ensemble of global hydrological models provides more robust estimates of the planned irrigation area when compared with the use any of the individual global models. The developed methodology shows that the hydrological modelling provides a potential improvement in irrigation planning when water supply is uncertain due to frequent droughts (Kaune et al. 2020). 
The last case study focussed on water quality in lake Peipsi, which is the largest transboundary lake in Europe. It is shared between Russia and Estonia. Due to nutrient pollution the lake frequently suffers from harmful cyanobacteria blooms. Current land use policies attempt to reduce the nutrient load in the lake in order to restore the lake water quality. The study analysed the effects of land use and lake management on water quality (Fink et al. 2018). This was achieved by combining hydrological modelling (WaterGAP3, WaterWorld), water quality modelling (WaterQUAL), analysis of Earth observation data of water quality (MERIS data), and in-situ data. The WaterGAP3 model simulated total phosphorous loads and water pollution by human impacts in lake Peipsi. The analysis of MERIS imagery provided accurate assessments of chlorophyll-a concentrations in lake Peipsi, with a high spatial and temporal resolution. With WaterWorld the impacts on water quality of scenarios of optimized land use and management were quantified. The best management options to reduce lake pollution are reductions of nutrient runoff from surrounding agricultural areas, as well as improving municipal and industrial waste water treatment.

\section{References}

Balsamo G, Beljaars A, Scipal K, Viterbo P, van den Hurk B, Hirschi M, Betts AK (2009) A revised hydrology for the ECMWF model: verification from field site to terrestrial water storage and impact in the integrated forecast system. J Hydrometeorol 10:623-643

Balsamo G, Albergel C, Beljaars A, Boussetta S, Brun E, Cloke H, Dee D, Dutra E, Muñoz-Sabater J, Pappenberger F, de Rosnay P, Stockdale T, Vitart F (2015) ERA-interim/land: a global land surface reanalysis data set. Hydrol Earth Syst Sci 19:389-407. https://doi.org/10.5194/hess-19-389-2015

Beck HE, van Dijk AIJM, Levizzani V, Schellekens J, Miralles DG, Martens B, de Roo A (2017) MSWEP. 2017. 3-hourly $0.25^{\circ}$ global gridded precipitation (1979-2015) by merging gauge, satellite, and reanalysis data. Hydrol Earth Syst Sci 21:589-615. https://doi.org/10.5194/hess-21-589-2017

Best MJ, Pryor M, Clark DB, Rooney GG, Essery RLH, Ménard CB, Edwards JM, Hendry MA, Porson A, Gedney N, Mercado LM, Sitch S, Blyth E, Boucher O, Cox PM, Grimmond CSB, Harding RJ (2011) The joint UK land environment simulator (JULES), model description - part 1: energy and water fluxes. Geosci Model Dev 4:677-699. https://doi.org/10.5194/gmd-4-677-2011

Decharme B, Alkama R, Douville H, Becker M, Cazenave A (2010) Global evaluation of the ISBA-TRIP continental hydrological system. Part II: Uncertainties in river routing simulation related to flow velocity and groundwater storage. J Hydrometeorol 11:601-617

Faures JM (2006) Mapping existing global systems \& initiatives background document - august 2006, prepared by FAO on behalf of the UN-water task force on monitoring Stockholm, 21 august 2006

Fink G, Burke S, Simis SGH, Kangur K, Kutser T, Mulligan M (2018) Management options to improve water quality in lake Peipsi: insights from large scale models and remote sensing. Water Resour Manage. https://doi.org/10.1007/s11269-018-2156-5

Flörke M, Kynast E, Bärlund I, Eisner S, Wimmer F, Alcamo J (2013) Domestic and industrial water uses of the past 60 years as a mirror of socio-economic development: a global simulation study. Glob Environ Chang 23:144-156

Haddeland I, Heinke J, Biemans H, Eisner S, Flörke M, Hanasaki N, Konzmann M, Ludwig F, Masaki Y, Schewe J, Stacke T, Tessler ZD, Wada Y, Wisser D (2014) Global water resources affected by human interventions and climate change. Proc Natl Acad Sci U S A 111:3251-3256

Hagemann S, Chen C, Clark DB, Folwell S, Gosling SN, Haddeland I, Hanasaki N, Heinke J, Ludwig F, Voss F, Wiltshire AJ (2013) Climate change impact on available water resources obtained using multiple global climate and hydrology models. Earth System Dynamics 4:129-144

Kaune A, López López P, Gevaert A, Veldkamp T, Werner M, de Fraiture C (2020) The benefit of using an ensemble of global hydrological models in surface water availability for irrigation area planning. Water Resour Manage. https://doi.org/10.1007/s11269-020-02544-1

Krinner G, Viovy N, de Noblet-Ducoudré N, Ogée J, Polcher J, Friedlingstein P, Ciais P, Sitch S, Prentice IC (2005) A dynamic global vegetation model for studies of the coupled atmosphere-biosphere system. Glob Biogeochem Cycles 19:GB1015. https://doi.org/10.1029/2003GB002199 
Lakew HB, Moges SA, Anagnostou EN, Nikolopoulos EI, Asfaw DH (2019) Evaluation of global water resources reanalysis runoff products for Local water resources applications: case study-upper Blue Nile Basin of Ethiopia. Water Resour Manage. https://doi.org/10.1007/s11269-019-2190-y

Lindström G, Johansson B, Persson M, Gardelin M, Bergström S (1997) Development and test of the distributed HBV-96 hydrological model. J Hydrol 201:272-288. https://doi.org/10.1016/S0022-1694(97)00041-3

López López P, Wanders N, Schellekens J, Renzullo LJ, Sutanudjaja EH, Bierkens MFP (2016) Improved largescale hydrological modelling through the assimilation of streamflow and downscaled satellite soil moisture observations. Hydrol Earth Syst Sci 20:3059-3076. https://doi.org/10.5194/hess-20-3059-2016

López López P, Sultana T, Hel Kafi MA, Hossain MS, Saleh Khan A, Masud MS (2020) Evaluation of global water resources reanalysis data for estimating flood events in the Brahmaputra River basin. Water Resour Manage. https://doi.org/10.1007/s11269-020-02546-Z

Orth R, Seneviratne SI (2013) Predictability of soil moisture and streamflow on sub-seasonal timescales: a case study. J Geophys Res-Atmos 118:10-963. https://doi.org/10.1002/jgrd.50846

Patz J, Campbell-Lendrum D, Holloway T, Jonathan AF (2005) Impact of regional climate change on human health. Nature 438:310-317. https://doi.org/10.1038/nature04188

Quintana-Segu P, Barella-Ortiz A, Regueiro-Sanfiz S, Miguez-Macho G (2019) The utility of land-surface model simulations to provide drought information in a water management context using global and local forcing datasets. Water Resour Manage. https://doi.org/10.1007/s11269-018-2160-9

Rodell M, Houser PR, Jambor U, Gottschalck J, Mitchell K, Meng C-J, Arsenault K, Cosgrove B, Radakovich J, Bosilovich M, Entin JK, Walker JP, Lohmann D, Toll D (2004) The global land data assimilation system. Bull Amer Meteor Soc 85:381-394

Rodríguez E, Sánchez I, Duque N, Arboleda P, Vega C, Zamora D, López López P, Kaune A, Werner M, García C, Burke S (2019) Combined use of local and global hydro meteorological data with hydrological models for water resources management in the Magdalena - Cauca Macro Basin - Colombia. Water Resour Manage. https://doi.org/10.1007/s11269-019-02236-5

Schellekens J, Dutra E, Martínez-de la Torre A, Balsamo G, van Dijk A, Sperna-Weiland F, Minvielle M, Calvet J-C, Decharme B, Eisner S, Fink G, Flörke M, Peßenteiner S, van Beek R, Polcher J, Beck H, Orth R, Calton B, Burke S, Dorigo W, Weedon GP (2017) A global water resources ensemble of hydrological models: the eartH2Observe Tier-1 dataset. Earth Syst Sci Data 9:389-413. https://doi.org/10.5194/essd-9-389-2017

Strohmeier S, López López P, Haddad M, Nangia V, Karrou M, Montanaro G, Boudhar A, Linés C, Veldkamp T, Sterk G (2019) Surface runoff and drought assessment using global water resources datasets - from Oum Er Rbia basin to the Moroccan country scale. Water Resour Manage. https://doi.org/10.1007/s11269-01902251-6

Sutanudjaja EH, van Beek R, Wanders N, Wada Y, Bosmans JHC, Drost N, van der Ent RJ, de Graaf IEM, Hoch JM, de Jong K, Karssenberg D, López López P, Peßenteiner S, Schmitz O, Straatsma MW, Vannametee E, Wisser D, Bierkens MFP (2018) PCR-GLOBWB 2: a 5 arcmin global hydrological and water resources model. Geosci Model Dev 11:2429-2453. https://doi.org/10.5194/gmd-11-2429-2018

Van Der Knijff JM, Younis J, De Roo APJ (2010) LISFLOOD: a GIS-based distributed model for river basin scale water balance and flood simulation. Int J Geograph Inform Sci 24:189-212. https://doi.org/10.1080 $/ 13658810802549154$

van Dijk AIJM, Peña-Arancibia JL, Wood EF, Sheffield J, Beck HE (2013) Global analysis of seasonal streamflow predictability using an ensemble prediction system and observations from 6192 small catchments worldwide. Water Resour Res 49:2729-2746. https://doi.org/10.1002/wrcr.20251

Weedon GP, Balsamo G, Bellouin N, Gomes S, Best MJ, Viterbo P (2014) The WFDEI meteorological forcing data set: WATCH Forcing Data methodology applied to ERA-Interim reanalysis data. Water Resour Res 50: 7505-7514. https://doi.org/10.1002/2014WR01563

Publisher's Note Springer Nature remains neutral with regard to jurisdictional claims in published maps and institutional affiliations. 